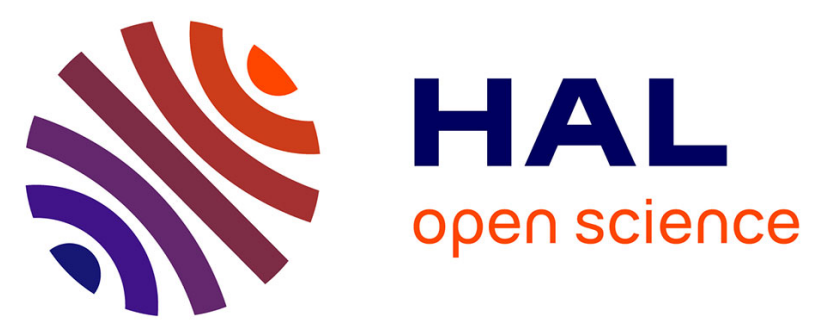

\title{
Self-testing for contact allergy to hair dyes - a 5-year follow-up multicentre study
}

\author{
Ulrik F. Friis, An Goosens, Ana M. Giménez-Arnau, Carola Lidén, Elena
}

Giménez-Arnau, Ian R. White, Jose H. Alfonso, Wolfgang Uter, Jeanne D.

Johansen

\section{To cite this version:}

Ulrik F. Friis, An Goosens, Ana M. Giménez-Arnau, Carola Lidén, Elena Giménez-Arnau, et al.. Selftesting for contact allergy to hair dyes - a 5-year follow-up multicentre study. Contact Dermatitis, 2017, 78 (2), pp.131-138. 10.1111/cod.12882 . hal-02119632

\section{HAL Id: hal-02119632 \\ https://hal.science/hal-02119632}

Submitted on 3 May 2019

HAL is a multi-disciplinary open access archive for the deposit and dissemination of scientific research documents, whether they are published or not. The documents may come from teaching and research institutions in France or abroad, or from public or private research centers.
L'archive ouverte pluridisciplinaire HAL, est destinée au dépôt et à la diffusion de documents scientifiques de niveau recherche, publiés ou non, émanant des établissements d'enseignement et de recherche français ou étrangers, des laboratoires publics ou privés. 
Title: Self-testing for contact allergy to hair dyes - a 5-year follow-up multicentre study

Authors: Ulrik F. Friis ${ }^{1}$, An Goosens ${ }^{2}$, Ana Giménez-Arnau ${ }^{3}$, Carola Lidén ${ }^{4}$, Elena Giménez-Arnau ${ }^{5}$, Ian R. White $^{6}$, Jose H. Alfonso ${ }^{7}$, Wolfgang Uter ${ }^{8}$, and Jeanne D. Johansen ${ }^{9}$.

${ }^{1}$ Research Centre for Hairdressers and Beauticians, Department of Dermatology and Allergy, Copenhagen University Hospital Gentofte, 2900 Hellerup, Denmark.

${ }^{2}$ Department of Dermatology, University Hospitals KU Leuven, 3000, Leuven, Belgium,

${ }^{3}$ Department of Dermatology, Hospital del Mar, Universitat Autónoma de Barcelona, 08003 Barcelona, Spain.

${ }^{4}$ Institute of Environmental Medicine, Karolinska Institutet, 17177 Stockholm, Sweden.

${ }^{5}$ Dermatolochemistry Laboratory, Université de Strasbourg-CNRS UMR 7177, 67081 Strasbourg, France.

${ }^{6}$ St John's Institute of Dermatology. London SE1 9RT, United Kingdom

${ }^{7}$ Department of Occupational Medicine and Epidemiology National Institute of Occupational Health, 0033 Oslo, Norway

${ }^{8}$ Department of Medical Informatics, Biometry and Epidemiology, Friedrich Alexander University, ErlangenNürnberg, 91054 Erlangen, Germany.

${ }^{9}$ The National Allergy Research Centre, Department of Dermatology and Allergy, Copenhagen University Hospital Gentofte, 2900 Hellerup, Denmark.

Correspondence:

Ulrik Fischer Friis.

Research Centre for Hairdressers and Beauticians,

Department of Dermatology and -Allergy, Copenhagen University Hospital Gentofte,

Kildegårdsvej 28, opgang 20A

DK-2900 Hellerup

Denmark

Tel: +4538677307

E-mail: Ulrik.fischer.friis@regionh.dk

Conflicts of interest: The authors declare that they have no conflicts of interest pertinent to the study subject.

Funding: The research centre for hairdresser and beauticians is funded by an unrestricted grant from the Danish Hairdressers' and Beauticians' Union and the Danish Hairdresser Association.

Author contribution:

All the authors contributed by collecting data on hair dyes products form their home country and by reviewing the article critically; UFF drafted the manuscript 


\begin{abstract}
Background

In 2011, a multicentre study was conducted in order to describe how hair dye manufacturers instructed consumers to do a self-test prior to dyeing their hair to identify individuals who are likely to react upon subsequent hair dyeing. A number of concerns were raised concerning the variability in instructions between products and producers, and the safety and validity of this tool.
\end{abstract}

\title{
Objectives
}

This 5 year follow-up study was to see if manufacturers still recommend a self-test and if so, if the procedures have been changed.

\section{Methods}

During March 2016 a total of 40 oxidative hair dye products from 21 different manufacturers were bought in retail stores in eight European countries.

\section{Results}

The consumers were instructed to do a self-test prior to hair dying for 39 of the products, however, the procedures greatly varied regarding the way of application, the amount, size, and skin site, the number of applications, rinsing or not, the reading times, and how a positive reaction should look.

\section{Conclusions}

The self-test is still recommended by almost all manufacturers of permanent hair dyes, but with major variations in the instructions, even in products from the same manufacturer. The concerns regarding safety and validity previously raised still remain.

Key words: self-testing, self-test, hair dyes, allergy alert test, skin alert test 


\section{Introduction}

Hair dyes contain different substances, some with allergenic properties (1-4), like $p$-phenylenediamine (PPD) (CAS no. 106-50-3), toluene-2,5-diamine (CAS no. 95-70-5), p-aminophenol (CAS no. 123-30-8), resorcinol (CAS no. 108-46-3) and in hair bleaching products the persulfates (ammonium-, potassium- and sodium persulfate (CAS no. 7727-54-0; 7727-21-1 and 7775-27-1)) (5-8).

In 2006 the European Commission's Scientific Committee on Consumer Products (SCCP) published a memorandum on substances in hair dyes and their skin sensitising properties, in which 27 substances met the EU criteria for classification as a skin sensitizer (R43/H317) (9). In 2013 they updated this memorandum, which now contains a list of 114 hair dye chemicals, for which 13 substances were classified as extreme, 23 as strong, and 20 as moderate sensitizers, based on OECD test guideline methods. This meant that 56 substances used in hair dyes met the EU criteria as a skin sensitizer (R43/H317) (10). The SCCP stated that substances fulfilling classification as R43/H317 may not be safe for the consumer, especially the ones that are categorized as extreme and strong sensitizers. This means that there is a risk for costumers of becoming sensitized, which is in accordance with the clinical experience that hair dyes sometimes cause severe allergic symptoms in consumers/customers $(6 ; 7)$ In 2011, a multicentre study was conducted in order to describe how hair dye manufacturers instructed consumers to do a self-test (also called 'allergy alert test' by industry) prior to dyeing their hair to identify individuals who are likely to react upon subsequent hair dyeing (11). A number of concerns were raised concerning the variability in instructions between products and producers and generally questioning the safety and validity of this tool. The EU Commission held a workshop on 'Skin Sensitivity Test' in April 2011 to help manufacturers address these issues. The aim of this study was to perform a 5 year follow-up to see if manufacturers still recommend a self-test and if so, if the procedures have been standardized.

\section{Methods}

During March 2016, a total of 40 permanent hair dye products from 21 different manufactures were bought in retail stores in eight countries (Belgium, Denmark, France, Germany, Norway, Spain, Sweden and the United Kingdom). In 39/40 (97.5\%) of products from 21 manufactures (Bysalerm, Casual Spa, Clairol, Eugène, Eugene Perma Paris, FarmaVita, Frank Provost, Garnier, Hardford AB Sweden, "Jihanna Laboratorium Kosmetyczne, Joanna Sp. Poland", Llongueras Colomer, L'Oreal, L'Oreal professional, Naturigin Organic Beauty, Phergal, Schwarzkopf, Syoss, TAHE, Tigi Int. Ltd, Vitanove \& Pascal Coste (Marque répère Eleclerc) and Wella), the consumer was instructed to do a self-test prior to hair dyeing. Thirty five of the products were commercial available and five was for professional use. The products for professional use were all bought in Belgium. We investigated instructions in the product leaflets for the 
self-test procedure for "amount of hair dye and suggested area size", "place of test", "re-application", "rinsing", "resting time" and "definition of positive allergic reaction".

\section{Results}

There was much variation in the instructions, (Table 1). Three instructions stated that the colouring agent should be oxidized [supposedly by mixing colouring agent and developer], five suggested that a mixture of colouring agent and developer should be applied, and the rest suggested to apply only the colouring agent or dyeing product (cream). The amount of hair dye to be applied on the skin ranged from "sufficient", "small amount", "a touch of", "a pinch of", "some" to "a thin layer". The suggested site for making the selftest varied from behind the ear, the earlobe, the elbow flexure, the upper arm, to no advice at all. The suggested size of the skin area for application ranged from "not specified", to 1-2 $\mathrm{cm}^{2}$, size of a EURO-cent coin $\left(2.1 \mathrm{~cm}^{2}\right)$, a 1-Danish-crown coin $\left(3.2 \mathrm{~cm}^{2}\right)$, a 1-Norwegian-crown coin $\left(3.5 \mathrm{~cm}^{2}\right)$ and a 10-Swedishcrown coin $\left(3.3 \mathrm{~cm}^{2}\right)$. For $10(35.7 \%)$ of the products up to 3 applications were recommended with reapplications "after drying". No applicator was suggested for four products, a piece of cotton wool for one, and a cotton bud for the others. No rinsing was recommended for 13 (32.5\%) products, for one product rinsing was to be performed after 30 minutes, for 13 products after 45 minutes, and for 12 products after 48 hours. The time before rinsing differed between the different products but also within the same manufacturer, see supplementary data. The time before reading was $48 \mathrm{~h}$ in all cases; for two products readings were also recommended after $45 \mathrm{~min}$ and after $24 \mathrm{~h}$, respectively. There was no consistent description on how a positive reaction should look, but the terms redness, itchy and swelling were mentioned in most of the product leaflet instructions.

\section{Discussion}

The results of this study show that no progress has been made the last 5 years, see

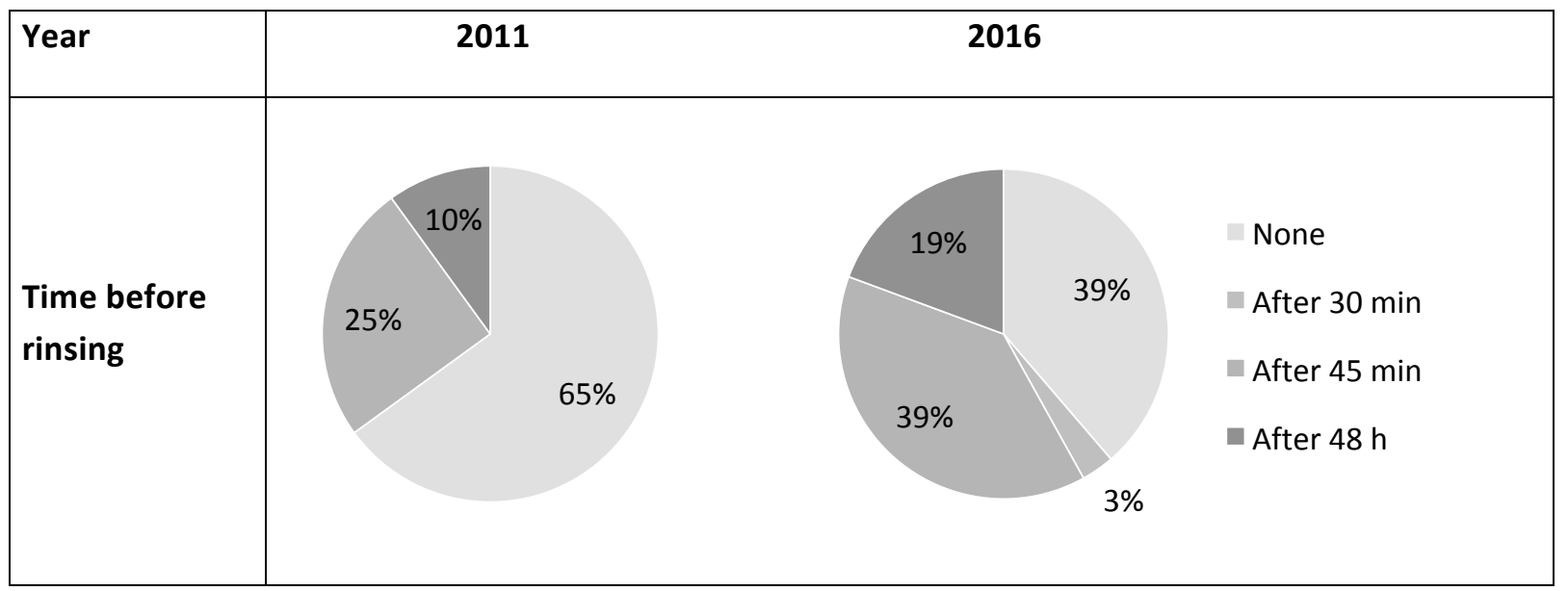




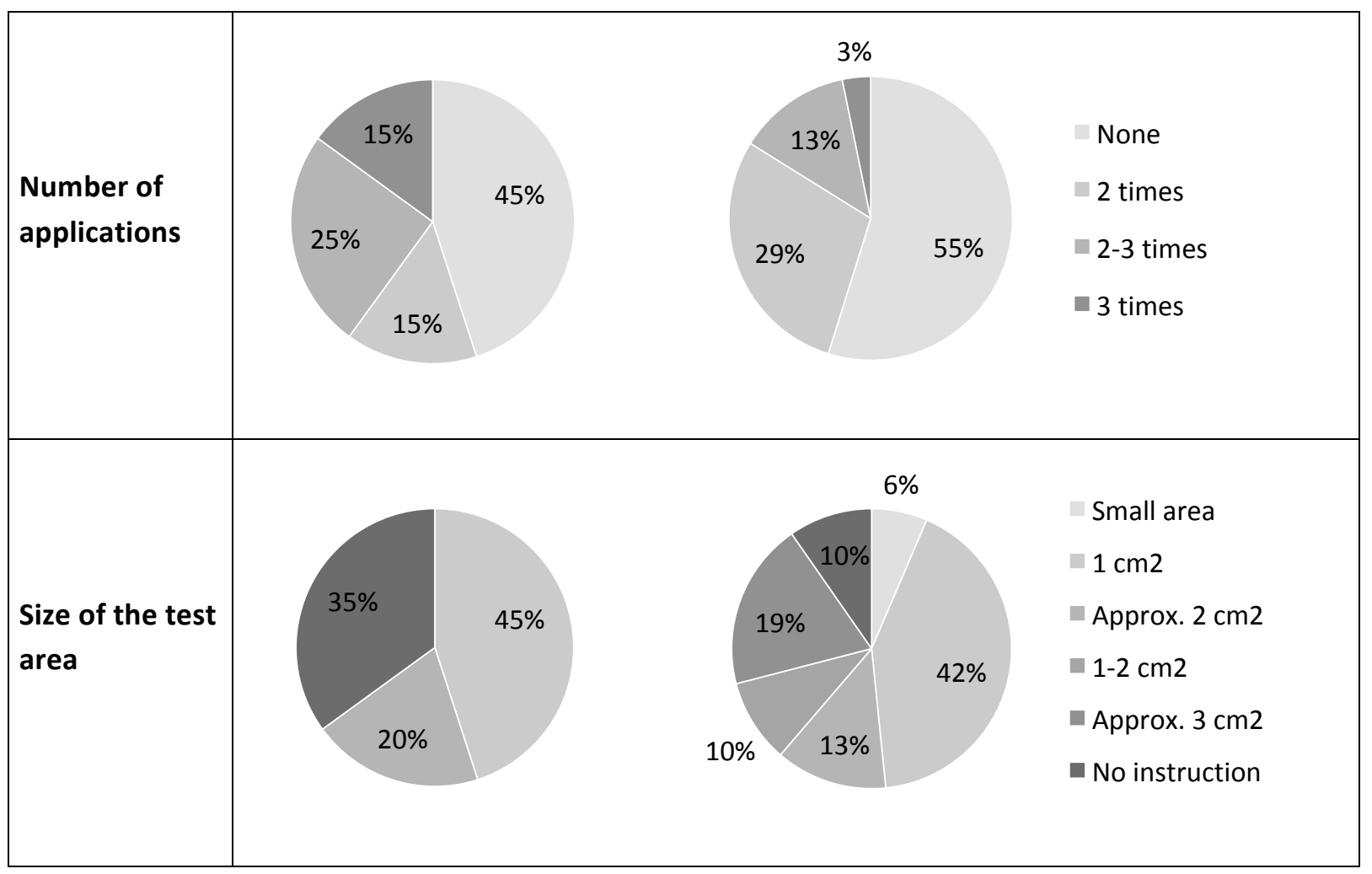

Legend

Figure 1. Comparison between hair dye product instructions on how to perform the self-test before hair dyeing in 2011 and 2016. Figures to the left are based on data in Table 2 ( $n=20)$ in Thyssen et al, 2012 (11). Figures to the right are based on data in the current study $(n=31)$. The size of the test area was sometimes compared with the size of coins (Table 1).

(11). The instructions still vary considerably, more than in the previous investigation and even between different hair dye products from the same manufacturer. The sample size in 2011 was relatively small by 17 different products from 13 different manufacturers, bought in 6 countries. This follow-up study is much larger, including 40 different hair dye products from 21 different manufacturers, bought in 8 different countries, and is therefore considered to be more representative. The leaflets were analysed concerning the same issues related to performing the self-test prior to hair-dyeing as 5 years ago, namely, (a) the amount of hair dye applied, (b) the number of applications, (c) when to rinse, (d) the resting time before reading and $(e)$ the definition of a positive reaction. In spite that several products were of the same brand and from the same manufacturer still major differences were found in the instructions, see Table 1 and the supplementary data. Cosmetics Europe - The Personal Care Association (the former European Cosmetics Toiletry and Perfumery Association - COLIPA) advises hair dye manufactures to recommend to the users of their products the self-test as a precaution against any allergic reaction to permanent hair dyes (12). 
Cosmetics Europe has made an on-line introduction on "how to do the 48 hour Allergy Alert Test?" (13). Here, they briefly inform that the manufactures may have slightly different ways to perform the test, and that it is based on their experience with the particular method, but also because of the variation of product formulations, packaging and applications (13). However, this cannot sensibly explain the major variations in instructions found in this study.

Thyssen et al. concluded in 2013 that the self-test has some limitations: (i) it is not a screening test but a diagnostic test; (ii) it has not been validated according to basic criteria defined by scientists; (iii) it has been evaluated in PPD allergic individuals, which is an inappropriate population for the evaluation of diagnostic performance, as the self-test is supposed to be used by persons who are not diagnosed with PPD allergy yet; (iv) skin reactions have been read by dermatologists and not by the targeted group (consumers and hairdressers); (v) hair dyes contain strong and extreme sensitizers that are left on the skin in high concentrations, potentially resulting in active sensitization; and (vi) recommendations and instructions on how to perform the hair dye self-test vary greatly, even among products from the same company, again suggesting that the basis for safe use of the test has not been determined (11).

In April 2011 a workshop was held by the EU Commission to help manufacturers develop a uniform protocol for pre-testing and perform risk assessment. This was reported to the subgroup on skin allergies on a meeting in the group November 2012, a subgroup under the EU Commission expert working group on Cosmetic Products (14). According to the minutes from the meeting the validation study should be launched by the industry in the first quarter of 2013 by testing selected PPD-positive hair dye allergic subject. This testing phase should last until 2015 when testing controls would be carried out. The analysis of the obtained data would be concluded by a study report in 2016. It is surprising that the study is carried out in PPD-allergic individuals again, as this is exactly a major criticism raised before: this is not the correct target group and therefore it cannot be predicted how the test will perform in consumers, who are not yet diagnosed with PPD allergy (11).

According to the minutes from the meeting of the Sub-Group on Skin Allergens 20 November 2012 (14) some Member States experts were concerned about this approach because the safety of the self-test had not been established yet. They expressed their concerns that industry continues to advise consumers to perform the self-test even though the test has not been validated. In 2012, the status of the test was that it was being investigated and until the result of that was available, the test should not be recommended to consumers. It was also suggested to have an opinion from the SCCS on the proof of concept study (14). Overall, the Member States experts were of the opinion that the proposed time plan was too long and that the alignment of the vast majority of the test parameters could have been done by industry much earlier. 
Industry agreed that such an alignment was feasible before the completion of the proof of concept study. Industry was to propose a harmonised approach for the parameters of the self-test by February 2013 (14). According to the minutes from the meeting in 2012, some Member States had the same concerns as outlined above in the paper by Thyssen et al $(11 ; 14)$. However, the current study shows that no changes have been made, no assessment of risk to the consumer by performing the test seems to have been done in spite being announced since 2012, and advice of doing the self-test is still given to every consumer buying a hair dye product.

\section{Conclusion}

In conclusion, the concerns regarding safety and validity previously raised still remain. It is of major concern that no assessment of the risk to the consumer of performing the test has been made, and no standardization has been performed. 
Reference List

(1) Boonchai W, Bunyavaree M, Winayanuwattikun W, Kasemsarn P. Contact sensitizers in commercial hair dye products sold in Thailand. Contact Dermatitis 2016: 74(4):222-9.

(2) Hamann D, Yazar K, Hamann CR, Thyssen JP, Lidén C. p-Phenylenediamine and other allergens in hair dye products in the United States: a consumer exposure study. Contact Dermatitis 2014: 70(4):213-8.

(3) Yazar K, Boman A, Lidén C. Potent skin sensitizers in oxidative hair dye products on the Swedish market. Contact Dermatitis 2009: 61(5):269-75.

(4) Thorén S, Yazar K. Contact allergens in 'natural' hair dyes. Contact Dermatitis 2016: 74(5):302-4.

(5) Kirchlechner S, Hübner A, Uter W. Survey of sensitizing components of oxidative hair dyes (retail and professional products) in Germany. J Dtsch Dermatol Ges 2016: 14(7):707-15.

(6) Schwensen JF, Johansen JD, Veien NK, Funding AT, Avnstorp C, Østerballe $M$, Andersen KE, Paulsen E, Mortz CG, Sommerlund M, Danielsen A, Andersen BL, Thormann J, Kristensen O, Kristensen B, Vissing S, Nielsen NH, Thyssen JP, Søsted H. Occupational contact dermatitis in hairdressers: an analysis of patch test data from the Danish Contact Dermatitis Group, 2002-2011. Contact Dermatitis 2014: 70(4):233-7.

(7) Søsted H, Rustemeyer T, Gonçalo M, Bruze M, Goossens A, Gimenez-Arnau AM, Le Coz CJ, White IR, Diepgen TL, Andersen KE, Agner T, Maibach H, Menné T, Johansen JD. Contact allergy to common ingredients in hair dyes. Contact Dermatitis 2013: 69(1):32-9.

(8) Yazar K, Boman A, Lidén C. p-Phenylenediamine and other hair dye sensitizers in Spain. Contact Dermatitis 2012: 66(1):27-32.

(9) Scientific Committee on Consumer Products. Memorandum on Hair Dye Substances and their Skin Sensitising Properties. 2006 Dec 19.

Available at: http://ec.europa.eu/health/ph_risk/committees/04_sccp/docs/sccp_s_05.pdf (last accessed 24-8-2016)

(10) Scientific Committee on Consumer Products. Memorandum on hair dye Chemical Sensitisation. 2013 Feb 26.

Available at: http://ec.europa.eu/health/scientific_committees/consumer_safety/docs/sccs_s_007.pdf (last accessed 24-8-2016)

(11) Thyssen JP, Søsted H, Uter W, Schnuch A, Giménez-Arnau AM, Vigan M, Rustemeyer T, Granum B, McFadden J, White JM, White IR, Goossens A, Menné T, Lidén C, Johansen JD. Self-testing for contact sensitization to hair dyes--scientific considerations and clinical concerns of an industry-led screening programme. Contact Dermatitis 2012: 66(6):300-11.

(12) Cosmetics Europe. Frequently asked questions - 3. What is the Allergy Alert Test? 2016. Available at: http://www.colourwell-colourwise.eu/faq.html. (Last accessed 24-8-2016). 
(13) Cosmetics Europe. How to do the 48 hour Allergy Alert Test? 2016. Available at: http://www.colourwell-colourwise.eu/allergy_alert.html. (Last accessed 24-8-2016).

(14) Anonymous. Minutes from the meeting of the Sub-Group on Skin Allergens . 20-11-2012. Available at: http://ec.europa.eu/transparency/regexpert/index.cfm. (Last accessed 25-9-2016). 
Table 1. Overview of the allergy self-test instructions found inside the $\mathbf{4 0}$ different hair dye products bought in the eight different countries ${ }^{1}$. Purchase: March 2016. $n=40$.

\begin{tabular}{|c|c|c|c|c|c|c|}
\hline \multicolumn{2}{|c|}{ Amount of hair dye and suggested area size } & Place of test & Number of application and if mentioned when & Rinsing & Resting time & Definition of positive allergic reaction \\
\hline \multirow[t]{8}{*}{$\begin{array}{l}\text { Apply " sufficient amount" } \\
(\mathrm{n}=10)\end{array}$} & $2 \mathrm{~cm}^{2}(\mathrm{n}=1)$ & no suggestions ( $n=1$ ) & Not specified - repeated 2-3 times $(n=1)$, & No rinse $(n=1)$ & $48 \mathrm{~h}(\mathrm{n}=1)$ & $\begin{array}{l}\text { Itch, pain, burning sensation, } \\
\text { erythema, swelling }(n=1)\end{array}$ \\
\hline & 1-crown coin* $(n=3)$ & Behind the ear $(n=3)$ & After drying - repeated 2 times $(n=3)$, & After $48 \mathrm{~h}(\mathrm{n}=3)$ & Up to $48 \mathrm{~h}(\mathrm{n}=3)$ & $\begin{array}{l}\text { Non-normal reaction such as itch, } \\
\text { redness, or swelling at or around the } \\
\text { area }(n=3)\end{array}$ \\
\hline & $\begin{array}{l}1 \text { Euro cent coin }{ }^{* * *} \\
(n=1)\end{array}$ & Behind the earlobe $(n=1)$ & Not specified - repeated 2 times $(n=1)$ & $\begin{array}{l}\text { No rinse and no } \\
\text { cover }(n=1)\end{array}$ & Up to $48 \mathrm{~h}(\mathrm{n}=1)$ & $\begin{array}{l}\text { Itch, erythema. Specification: do not } \\
\text { use once the age is }<16(n=1)\end{array}$ \\
\hline & $1 \mathrm{~cm}^{2}(n=4)$ & Inner elbow $(n=1)$ & Not specified - repeated 1 times $(n=1)$, & No rinse $(n=1)$ & Up to $48 \mathrm{~h}(\mathrm{n}=1)$ & Burning sensation, erythema $(n=1)$ \\
\hline & & no suggestions $(\mathrm{n}=1)$ & Not specified - repeated 2 times $(n=1)$ & No rinse $(n=1)$, & Up to $48 \mathrm{~h}(\mathrm{n}=1)$ & Burning sensation, erythema $(n=1)$ \\
\hline & & no suggestions $(\mathrm{n}=1)$ & Not specified - repeated 2-3 times $(n=1)$ & No rinse $(n=1)$, & $48 \mathrm{~h}(\mathrm{n}=1)$ & Itch, erythema $(n=1)$ \\
\hline & & Behind the earlobe $(n=1)$ & It's not specified - repeated 1 time $(n=1)$, & No rinse $(n=1)$ & Up to $48 \mathrm{~h}(\mathrm{n}=1)$ & $\begin{array}{l}\text { Itch, erythema. Specification: do not } \\
\text { use once the age is }<16(n=1)\end{array}$ \\
\hline & $1-2 \mathrm{~cm}^{2}(\mathrm{n}=1)$ & Behind the earlobe $(n=1)$ & Not specified - repeated 3 times $(n=1)$ & No rinse $(n=1)$ & Up to $48 \mathrm{~h}(\mathrm{n}=1)$ & Itch, erythema $(n=1)$ \\
\hline \multirow{4}{*}{$\begin{array}{l}\text { Sufficient amount of } \\
\text { colouring agent }(n=4)\end{array}$} & 1 Euro cent $\operatorname{coin}^{* * *}$ & Behind the ear $(n=3)$ & 2 times $(n=1)$ & No rinse $(n=1)$ & $48 \mathrm{~h}(\mathrm{n}=1)$ & Itching, redness, swelling $(n=1)$ \\
\hline & & & $2-3$ times $(n=1)$ & No rinse $(n=1)$ & $48 \mathrm{~h}(\mathrm{n}=1)$ & Itching, redness, swelling $(n=1)$ \\
\hline & & & Repeated $(n=1)$ & No rinse $(n=1)$ & $48 \mathrm{~h}(\mathrm{n}=1)$ & Itching, redness, swelling $(n=1)$ \\
\hline & $1-2 \mathrm{~cm}^{2}(\mathrm{n}=1)$ & Behind the ear $(n=1)$ & 2 times $(n=1)$ & No rinse $(n=1)$ & $48 \mathrm{~h}(\mathrm{n}=1)$ & Itching, redness, swelling $(\mathrm{n}=1)$ \\
\hline \multirow{2}{*}{$\begin{array}{l}\text { Small quantity of colouring } \\
\text { agent }(n=2)\end{array}$} & $1 \mathrm{~cm}^{2}(\mathrm{n}=1)$ & Inner elbow $(\mathrm{n}=1)$ & 1 time $(n=1)$ & After $45 \min (n=1)$ & $48 h(n=1)$ & Any reaction $(n=1)$ \\
\hline & $1-2 \mathrm{~cm}^{2}(\mathrm{n}=1)$ & $\begin{array}{c}\text { Forearm or behind the } \\
\text { ear }(n=1)\end{array}$ & 1 time $(n=1)$ & After $48 \mathrm{~h}(\mathrm{n}=1)$ & $48 \mathrm{~h}(\mathrm{n}=1)$ & Itching, redness, swelling $(n=1)$ \\
\hline $\begin{array}{l}\text { Small quantity of unmixed } \\
\text { colourant product (creme } \\
\text { colourant tube) }(n=1)\end{array}$ & $1-2 \mathrm{~cm}^{2}(\mathrm{n}=1)$ & Behind the ear $(n=1)$ & After drying - repeated 2 times $(n=1)$ & After $45 \mathrm{~h}(\mathrm{n}=1)$ & $48 \mathrm{~h}(\mathrm{n}=1)$ & $\begin{array}{l}\text { Any abnormal reactions, such as } \\
\text { itching, redness or swelling in or } \\
\text { around the test area }(n=1)\end{array}$ \\
\hline $\begin{array}{l}\text { Small amount of colour } \\
\text { cream in a thin layer }(n=1)\end{array}$ & $1 \mathrm{~cm} * 1 \mathrm{~cm}(\mathrm{n}=1)$ & Inside of the elbow $(n=1)$ & Not applicable - repeated 1 time $(n=1)$ & After $45 \min (n=1)$ & Up to $48 \mathrm{~h}(\mathrm{n}=1)$ & Any reaction $(n=1)$ \\
\hline $\begin{array}{l}\text { Small amount of colour } \\
\text { cream }(n=1)\end{array}$ & Not specified $(n=1)$ & Inside of the elbow $(n=1)$ & Not applicable - repeated 1 time $(n=1)$ & After $45 \min (n=1)$ & Up to $48 \mathrm{~h}(\mathrm{n}=1)$ & Redness or itch $(n=1)$ \\
\hline $\begin{array}{l}\text { Small amount of colour } \\
\text { cream mixed with oxidizer in } \\
\text { a thin layer }(n=1)\end{array}$ & Not specified $(n=1)$ & Inside of the elbow $(n=1)$ & Not applicable - repeated 1 time $(n=1)$ & After $45 \min (n=1)$ & Up to $48 \mathrm{~h}(\mathrm{n}=1)$ & Any reaction $(\mathrm{n}=1)$ \\
\hline A thin layer $(n=1)$ & $1 \mathrm{~cm} * 1 \mathrm{~cm}(\mathrm{n}=1)$ & Inside of the elbow $(n=1)$ & Not applicable - repeated 1 time $(n=1)$ & After $45 \min (n=1)$ & Up to $48 \mathrm{~h}(\mathrm{n}=1)$ & Any reaction $(\mathrm{n}=1)$ \\
\hline $\begin{array}{l}\text { A touch of dyeing cream } \\
(n=1)\end{array}$ & $1 \mathrm{~cm}^{2}(\mathrm{n}=1)$ & $\begin{array}{l}\text { Elbow crease, upper arm } \\
(n=1)\end{array}$ & Not applicable - repeated 1 time $(n=1)$ & $\begin{array}{l}\text { After } 45 \text { min, with } \\
\text { warm water }(n=1)\end{array}$ & $\begin{array}{l}\text { Reading at } 45 \\
\min \text { and } 48 \mathrm{~h} \\
(\mathrm{n}=1)\end{array}$ & $\begin{array}{l}\text { Tingling-, burning-, blackout feeling, } \\
\text { redness, itching, eczema, bulling, } \\
\text { swelling of eyes or face, weeping } \\
(n=1)\end{array}$ \\
\hline $\begin{array}{l}\text { A "pinch" amount of colour } \\
\text { cream and the activator } \\
(\mathrm{n}=1)\end{array}$ & $1 \mathrm{~cm} * 1 \mathrm{~cm}(\mathrm{n}=1)$ & Inside of the elbow $(n=1)$ & Not applicable - repeated 1 time $(n=1)$ & After $45 \min (n=1)$ & Up to $48 \mathrm{~h}(\mathrm{n}=1)$ & Any reaction $(\mathrm{n}=1)$ \\
\hline $\begin{array}{l}\text { Not defined: some ["etwas" } \\
(\text { some)] }(n=1)\end{array}$ & $1 \mathrm{~cm} * 1 \mathrm{~cm}(\mathrm{n}=1)$ & no suggestions $(\mathrm{n}=1)$ & Not applicable - repeated 1 time $(n=1)$ & $\begin{array}{l}\text { Rinse thoroughly } \\
\text { after } 45 \mathrm{~min}\end{array}$ & $48 h(n=1)$ & "reactions" ( $n=1)$ \\
\hline \multirow[t]{2}{*}{$\begin{array}{l}\text { Apply "sufficient amount", } \\
\text { not mixed }(\mathrm{n}=2)\end{array}$} & $\begin{array}{l}\text { 1-crown coin* } \\
(n=2),\end{array}$ & Behind the ear $(n=2)$ & After drying - repeated 2 times $(n=2)$ & $\begin{array}{l}\text { Not mentioned. } \\
\text { Area should not be } \\
\text { touched, washed or } \\
\text { covered for } 48 \mathrm{~h} \\
(\mathrm{n}=2)\end{array}$ & $48 \mathrm{~h}(\mathrm{n}=2)$ & $\begin{array}{l}\text { Any abnormal reactions, such as } \\
\text { itching, redness or swelling in or } \\
\text { around the test area }(n=2)\end{array}$ \\
\hline & $1-2 \mathrm{~cm}^{2}(\mathrm{n}=1)$ & Behind the ear $(n=1)$ & After drying - repeated 2 times $(n=1)$ & After $48 \mathrm{~h}(\mathrm{n}=1)$ & $48 \mathrm{~h}(\mathrm{n}=1)$ & $\begin{array}{l}\text { Itching, redness or skin rash, swelling } \\
(n=1)\end{array}$ \\
\hline Sufficient quantity $(n=2)$ & $\begin{array}{l}1 \text { Euro cent coin } * * * \\
(n=2)\end{array}$ & Behind the ear $(n=2)$ & After drying - repeated 2-3 times $(n=2)$ & $\begin{array}{l}\text { Not mentioned. } \\
\text { Area should not be } \\
\text { touched, washed or } \\
\text { covered for } 48 \mathrm{~h} \\
(\mathrm{n}=2)\end{array}$ & $48 \mathrm{~h}(\mathrm{n}=2)$ & Red or itchy or swollen skin $(n=2)$ \\
\hline $\begin{array}{l}\text { Small amount of colour } \\
\text { cream in a thin layer }(n=2)\end{array}$ & $1 \mathrm{~cm} * 1 \mathrm{~cm}(\mathrm{n}=2)$ & In the elbow fold $(n=2)$ & Not applicable - repeated 1 time $(n=2)$ & $\begin{array}{c}\text { After } 45 \text { min. With } \\
\text { warm water. Avoid } \\
\text { covered and } \\
\text { contact with textile } \\
(\mathrm{n}=2)\end{array}$ & $48 \mathrm{~h}(\mathrm{n}=2)$ & Any reaction $(\mathrm{n}=2)$ \\
\hline \multirow{2}{*}{$\begin{array}{l}\text { Small amount of mixture } \\
\text { hair dye developer } \\
\text { ("révélateur"-hydrogen } \\
\text { peroxide) ( } n=1)\end{array}$} & $1 \mathrm{~cm}^{2}(\mathrm{n}=1)$ & $\begin{array}{l}\text { Behind the ear or elbow } \\
\text { crease }(n=1)\end{array}$ & Not applicable - repeated 1 time $(n=1)$ & After $48 \mathrm{~h}(\mathrm{n}=1)$ & $48 \mathrm{~h}(\mathrm{n}=1)$ & $\begin{array}{l}\text { Redness, tingling feeling, itching, } \\
\text { swelling of eyes or face }(n=1)\end{array}$ \\
\hline & $\begin{array}{l}\text { just mentioned } \\
\text { "small surface" } \\
(n=1)\end{array}$ & $\begin{array}{l}\text { Behind the ear or elbow } \\
\text { crease or upper arm }(n=1)\end{array}$ & Not applicable - repeated 1 time $(n=1)$ & After $30 \min (n=1)$ & $48 \mathrm{~h}(\mathrm{n}=1)$ & $\begin{array}{l}\text { Redness, tingling feeling, itching } \\
\qquad(\mathrm{n}=1)\end{array}$ \\
\hline Thin layer of mixture & $1 \mathrm{~cm}^{2}(\mathrm{n}=1)$ & Inner elbow $(n=1)$ & 1 time $(n=1)$ & After $45 \min (n=1)$ & $48 \mathrm{~h}(\mathrm{n}=1)$ & Any reaction $(\mathrm{n}=1)$ \\
\hline $\begin{array}{l}\text { Sufficient amount of mixture } \\
(n=1)\end{array}$ & $1 \mathrm{~cm}^{2}(\mathrm{n}=1)$ & $\begin{array}{l}\text { Behind the ear or elbow } \\
\text { crease }(n=1)\end{array}$ & 1 time $(n=1)$ & No rinse $(n=1)$ & $48 \mathrm{~h}(\mathrm{n}=1)$ & Rash, stinging, itching $(n=1)$ \\
\hline $\begin{array}{l}\text { Quantity unspecific of } \\
\text { mixture }(n=1)\end{array}$ & $1 \mathrm{~cm}^{2}(\mathrm{n}=1)$ & $\begin{array}{l}\text { Behind the ear or elbow } \\
\text { crease }(n=1)\end{array}$ & $2-3$ times $(n=1)$ & No rinse $(n=1)$ & $48 \mathrm{~h}(\mathrm{n}=1)$ & Any reaction $(n=1)$ \\
\hline Not specified ( $n=1)$ & $\begin{array}{c}\text { 10-crown coin** or } \\
1 \mathrm{~cm} 2(\mathrm{n}=1)\end{array}$ & Behind the ear $(n=1)$ & Not applicable - repeated 1 time $(n=1)$ & After $45 \min (n=1)$ & Up to $48 \mathrm{~h}(\mathrm{n}=1)$ & $\begin{array}{c}\text { Swelling, itch, redness at or around } \\
\text { the area }(n=1)\end{array}$ \\
\hline $\begin{array}{l}\text { a small quantity of the hair } \\
\text { dye as prepared for use } \\
(n=1)\end{array}$ & $\begin{array}{c}\text { a small area of skin } \\
(n=1)\end{array}$ & $\begin{array}{l}\text { behind the ear or on the } \\
\text { inner surface of the } \\
\text { forearm }(n=1)\end{array}$ & Not applicable - repeated 1 time $(n=1)$ & $\begin{array}{l}\text { After } 48 \text { hour with } \\
\text { soap and water } \\
(\mathrm{n}=1)\end{array}$ & $\begin{array}{c}24 \text { and } 48 h \\
(n=1)\end{array}$ & $\begin{array}{l}\text { Any reaction (such as swelling, } \\
\text { redness, itching, eczema, blistering } \\
\text { etc) ( } n=1)\end{array}$ \\
\hline $\begin{array}{l}\text { Mix a small amount of tint } \\
\text { and developer. Apply } \\
\text { mixture to test area(n=1) }\end{array}$ & $1 \mathrm{~cm}^{2}(\mathrm{n}=1)$ & Bend of your elbow $(n=1)$ & Not applicable - repeated 1 time $(n=1)$ & After $45 \min (n=1)$ & Up to $48 \mathrm{~h}(\mathrm{n}=1)$ & $\begin{array}{l}\text { Any signs of rash, redness, swelling, } \\
\text { burning, itching or similar }(n=1)\end{array}$ \\
\hline $\begin{array}{l}\text { No recommendations of an } \\
\text { self-test }(n=1)(n=1)\end{array}$ & - & - & & - & - & - \\
\hline
\end{tabular}

\footnotetext{
${ }^{1}$ Belgium, Denmark, France, Germany, Norway, Spain, Sweden and the United Kingdom
} 
* A crown coin could either be a Danish $\left(\sim 3.2 \mathrm{~cm}^{2}\right)$ or a Norwegian $\left(\sim 3.5 \mathrm{~cm}^{2}\right)$ one crown coin. ${ }^{* *}$ A Swedish 10-crown coin $\left(\sim 3.3 \mathrm{~cm}^{2}\right) .{ }^{* * *}$ A EURO-cent coin $\left(2.1 \mathrm{~cm}^{2}\right)$. 


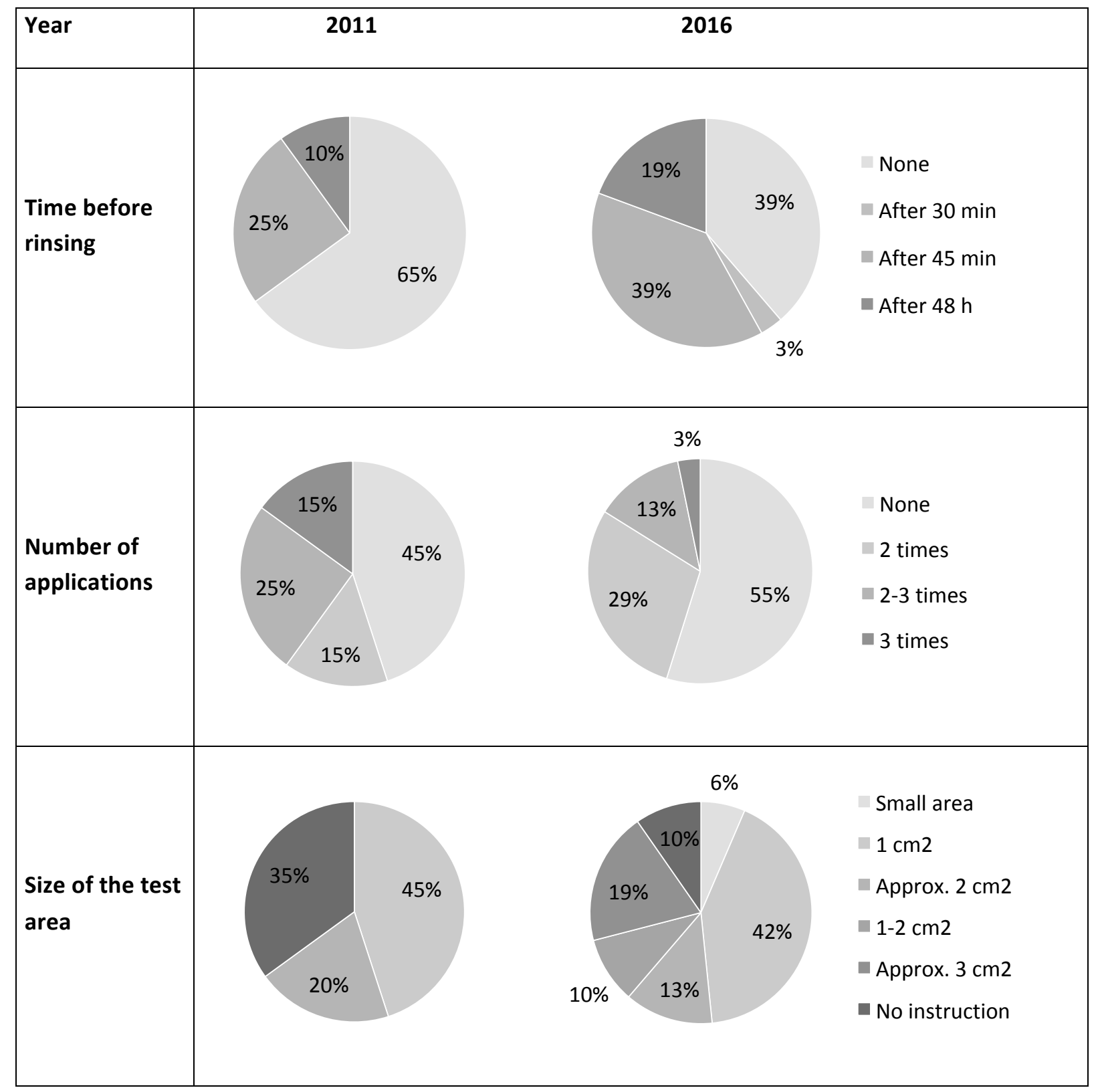

\section{Legend}

Figure 1. Comparison between hair dye product instructions on how to perform the self-test before hair dyeing in 2011 and 2016. Figures to the left are based on data in Table 2 ( $n=20$ ) in Thyssen et al, 2012 (11). Figures to the right are based on data in the current study $(n=31)$. The size of the test area was sometimes compared with the size of coins (Table 1). 